\title{
Water quality assessment using macroinvertebrates along the mining area of Brgy
}

\author{
Queenilyn B. Albutra ${ }^{1}$ * , Cordulo P. Ascaño II ${ }^{2}$, Cesar G. Demayo ${ }^{1}$ \\ ${ }^{1}$ Department of Biological Sciences, College of Science and Mathematics, Mindanao State University - Iligan Institute of \\ Technology, Iligan, Philippines \\ ${ }^{2}$ Department of Environmental Science and Technology, College of Science and Mathematics, University of Science and \\ Technology of Southern Philippines, Cagayan de Oro, Philippines
}

\section{ARTICLE INFO}

\section{Article history:}

Received 12 February 2017

Received in revised form

12 September 2017

Accepted 13 September 2017

\section{Keywords:}

Small scale gold mining mercury

Macroinvertebrates

Bioindicators

\begin{abstract}
A B S T R A C T
In this research, water quality assessment in the Bigaan River, Brgy. Gango, Libona, Bukidnon was conducted to determine the impact of small scale mining on the aquatic ecosystem using macroinvertebrates as bioindicators. Analysis revealed that total suspended solid, total hardness and mercury content is higher in the downstream portion of the river. Species composition of macroinvertebrates differs between sites. Total abundance and species diversity is higher in the upstream portion of the river. The absence of pollution sensitive Ephemeroptera (Mayfly) and Tricoptera (Caddisfly) taxa in the downstream portion of the river indicates that the water quality is deteriorating. Although the level of mercury contamination in the downstream portion is low and within the standard limit, the outcome still indicates that long term exposure to mercury brought by small scale gold mining has detrimental effects on macroinvertebrate communities and on the quality and functionality of the river ecosystem.
\end{abstract}

(C) 2017 The Authors. Published by IASE. This is an open access article under the CC BY-NC-ND license (http://creativecommons.org/licenses/by-nc-nd/4.0/)

\section{Introduction}

Small-scale gold mining (SGM) embroils the extraction of minerals, usually gold, using undeveloped techniques in small or medium sized operations. Commonly, it involves the use of considerable amount of mercury during mineral processing because it is inexpensive and simple to use (UNEP, 2008). Globally, SGM is responsible for approximately $37 \%$ of mercury emissions and is considered the largest source of water mercury pollution (UNEP, 2013a). Mining hotspots, which are identified sites of high metallic mercury concentration situated usually near flowing river, are the major source of mercury dispersion into aquatic ecosystems. Additionally, mercury-containing tailings are usually dumped in or beside bodies of water which results mercury contamination of soil, rivers, streams, ponds and lakes for a very long period of time (UNEP, 2008).

Mercury that contaminates into the bodies of water will be transformed by anaerobic

\footnotetext{
* Corresponding Author

Email Address: queenilyn_albutra@yahoo.com (Q. B. Albutra) https://doi.org/10.21833/ijaas.2017.011.015

2313-626X/C 2017 The Authors. Published by IASE.

This is an open access article under the CC BY-NC-ND license

(http://creativecommons.org/licenses/by-nc-nd/4.0/)
}

microorganisms into its more toxic form, methylmercury. Methylmercury that formed is then absorbed by phytoplankton, ingested by zooplankton then by macroinvertebrates and eventually goes up into the food chain which becomes concentrated in fishes particularly in carnivorous species (WHO, 2007; UNEP, 2013b). Individuals exposed to mercury can develop changes in behavior, physiology, reproduction as well as acute effects which include morbidity and mortality. At the species level, changes in survivorship and population structure in addition to population declines or local extinction can be the endpoints of mercury exposure. Lastly, changes in the interaction among species and in the pattern of energy use and production are considered to be the ecological endpoints.

In water quality assessment, the used of biological indicators was adopted since most of the ecological and environmental bioindicators have strong association with some characteristics of their environment (McGeogh, 1998; Kitching et al., 2000; Davis et al., 2001) and thus more efficient in detecting long-term changes in water quality (Benetti et al., 2012). Among the communities that are considered bioindicators of water quality, the most frequently used are the benthic macroinvertebrates (Bonada et al., 2006). 
Macroinvertebrates are visible to unaided eyes, have sedentary and long life span and are significantly sensitive to organic pollution, thermal pollution, substrate alteration and toxic substances (Sharma et al., 2008). It has limited migration ability making them suitable for assessing the site specific impacts of certain environmental stressors. Furthermore, their assemblages are made up of species that constitute a broad range of trophic levels and pollution tolerances (Kripa et al., 2013). In this study, assessment in the upstream and downstream portion of Bigaan River was done using different physico-chemical parameters and macroinvertebrates' diversity and distribution to determine the impact of an active small-scale gold mining in Brgy. Gango, Libona, Bukidnon that uses mercury during gold extraction in the water quality of the river.

\section{Methodology}

\subsection{Research settings}

The study was conducted in the Bigaan River located at Barangay Gango, Libona, Bukidnon where an active small-scale gold mining exists. Brgy. Gango is bounded on the north by Misamis Oriental; on the south by Barangay Kinawe; on the east by Cugman River and on the western side by Bobonawan River. As shown in Fig. 1, the study area was divided into two sampling stations; the upstream $\left(8^{\circ} 24^{\prime} 29.82^{\prime \prime} \mathrm{N}\right.$ and $\left.124^{\circ} 40^{\prime} 29.40^{\prime \prime} \mathrm{E}\right)$ and downstream $\left(8^{\circ} 23^{\prime}\right.$ 57.24" N and 124 40' 39.12" E) portion of Bigaan River. The sampling station at the upstream portion of Bigaan River is situated prior to the area where small-scale gold mining activities exist.

\subsection{Collection of data}

Data were collected within the $100 \mathrm{~m}$ transect line established in each of the sampling station: upstream and downstream portion of Bigaan River. Data for the physicochemical parameters including the width and depth of stream, type of substrate, water current, temperature and $\mathrm{pH}$ were taken in situ while total suspended solid (TSS), dissolved oxygen (DO), biological oxygen demand (BOD), total hardness and mercury content were determined through laboratory analysis. All of the parameters were taken once with three replicates. For the macroinvertebrates, opportunistic sampling was employed using grab method and dip net method. Collected samples from each sampling station were put in separate containers containing $70 \%$ ethanol and were brought to the laboratory for processing and identification using different photographic identification keys.

\subsection{Analysis of data}

Data obtained from the physico-chemical parameters in both sampling stations were compared to the standards set by DENR Administrative Order (DAO) 34 under class C standards. Diversity indices were calculated using the PAST software version 2.14 to determine and compare the species diversity of macroinvetebrates in the upstream and downstream portion of Bigaan River.

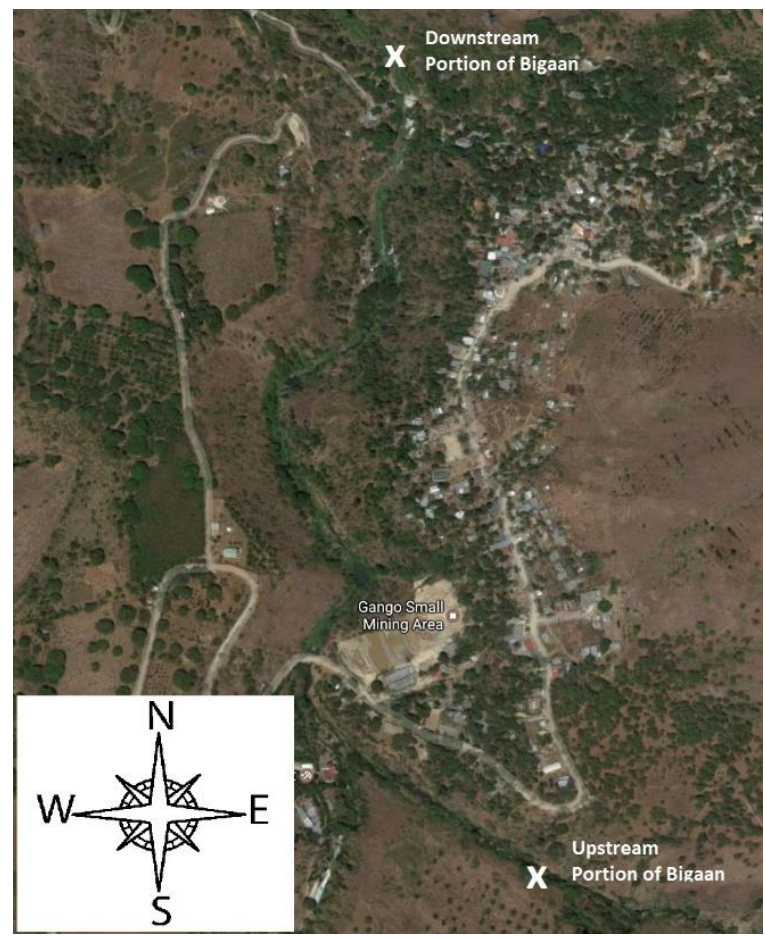

Fig. 1: Satellite view of the study area in Brgy. Gango,

Libona, Bukidnon showing the two sampling stations in Bigaan River (courtesy of Google Earth)

\section{Results and discussion}

Analysis in the water samples revealed variations in the physicochemical aspects between the downstream and upstream portion of Bigaan River in Brgy. Gango, Libona, Bukidnon. Table 1 shows the result of the physicochemical analysis between the 2 sampling stations as well as the corresponding standards set by DAO-34 (Class C). The total hardness and total suspended solid (TSS) are notably higher in the downstream portion of Bigaan River as compared to the upstream portion and have even exceeded the standard limit set by DAO-34. The observed difference in the TTS between the sampling stations might be attributed to the existing land used in the downstream portion of the river particularly the mining activities that discharges soil particles from the underground tunnel during the excavation process. Conversely, the average water temperature and $\mathrm{pH}$ in the downstream portion is marginally lower than the upstream portion. As compared to the standard, the $\mathrm{pH}$ values in both sampling stations have exceeded the standard set by DAO-34. Furthermore, the temperature of the water can affect the amount of dissolved oxygen in it; as the water gets warmer, it cannot hold as much as dissolve oxygen as in colder water causing the level of dissolved oxygen to drop (Hickin, 1995). 
Table 1: Physico-chemical parameters of the 2 sampling stations in Bigaan River, Brgy. Gango, Libona, Bukidnon

\begin{tabular}{cccc}
\hline Physico-chemical Parameters & Downstream & Upstream & DAO-34 Standards \\
\hline Width of the Stream & $13.77 \mathrm{~m}$ & $9.17 \mathrm{~m}$ & - \\
Depth of the Stream & $0.37 \mathrm{~m}$ & $0.39 \mathrm{~m}$ & - \\
Type of Substrate & Rocky-sandy & Rocky-sandy & - \\
Water Current & $0.20 \mathrm{~m} / \mathrm{s}$ & $0.36 \mathrm{~m} / \mathrm{s}$ & - \\
Total Hardness as CaCO3 & $201 \mathrm{mg} / \mathrm{L}$ & $159 \mathrm{mg} / \mathrm{L}$ & - \\
Temperature & $26.06^{\circ} \mathrm{C}$ & $26.60^{\circ} \mathrm{C}$ & $3^{\circ} \mathrm{C} \mathrm{rise}$ \\
$\mathrm{pH}$ & 8.71 & 8.74 & $6.5-8.5$ \\
Total Suspended Solid (TSS) & $80 \mathrm{mg} / \mathrm{L}$ & $<6 \mathrm{mg} / \mathrm{L}^{*}$ & $\leq 30 \mathrm{mg} / \mathrm{L} \mathrm{rise}$ \\
Dissolved Oxygen (DO) & $7.9 \mathrm{mg} / \mathrm{L}$ & $7.0 \mathrm{mg} / \mathrm{L}$ & $5.0 \mathrm{mg} / \mathrm{L}(\mathrm{min})$ \\
Biological Oxygen Demand (BOD) & $<1 \mathrm{mg} / \mathrm{L}^{*}$ & $<1 \mathrm{mg} / \mathrm{L}^{*}$ & $7.0 \mathrm{mg} / \mathrm{L}$ \\
Mercury Content & $0.002 \mu \mathrm{m} / \mathrm{ml}$ & $<0.001 \mu \mathrm{g} / \mathrm{ml} *$ & $0.002 \mu \mathrm{\mu g} / \mathrm{mL}$ \\
\hline \multicolumn{4}{c}{ Legend: ${ }^{*}$ - method detection limit; ${ }^{* *}$ - reporting limit }
\end{tabular}

Hence, the slight lower temperature in the downstream portion of the river might cause the dissolved oxygen in the water to be slightly higher as compared to the upstream portion. Lastly, the presence of mercury in the downstream portion can be attributed to the small scale mining activities occurring in the area which uses mercury for gold extraction. However, as compared to the standard set by DAO-34, the amount of mercury recorded in the downstream portion is still within the acceptable limit.

Collectively, as shown in Table 2, a total of 10 macroinvertebrates species that belongs to 8 different orders were collected in the 2 sampling stations of Bigaan River.

Table 2: Species composition and abundance of macroinvertebrates in the 2 sampling stations of Bigaan River, Brgy. Gango,

\begin{tabular}{ccccc}
\multicolumn{5}{c}{ Libona, Bukidnon } \\
\hline Order & Common Name & Down-stream & Up-stream & Total \\
\hline \multirow{2}{*}{ Coleoptera } & Water-penny beetle & 3 & 19 & 22 \\
& Whirligig beetle & 0 & 6 & 6 \\
Ephemeroptera & Mayfly nymph & 0 & 141 & 141 \\
Gnathobdellida & Leech & 129 & 14 & 143 \\
& Creeping water bug & 2 & 0 & 2 \\
Hemiptera & Water strider & 25 & 232 & 257 \\
Lepidoptera & Pyralid caterpillar & 19 & 0 & 19 \\
Lumbriculida & Aquatic worm & 7 & 0 & 7 \\
Mesogastropoda & Golden apple snail & 5 & 34 & 39 \\
Tricoptera & Caddisfly larvae & 0 & 66 & 66 \\
& Total & 190 & 512 & 702 \\
\hline
\end{tabular}

The number of macroinvertebrates species found in the downstream and upstream portion of the Bigaan River is the same but the species composition varied. Creeping water bug, pyralid caterpillar and aquatic worm were found only in the downstream portion while whirligig beetle, mayfly nymph and caddisfly larvae were found only in the upstream portion. In terms of the macroinvertebrates' abundance, the upstream portion has considerably higher number of collected macroinvertebrates than the downstream portion. Water strider is the most abundant in the upstream while leech is the most abundant species in the downstream. Based on the different diversity indices of macroinvertebrates shown in Table 3, the species diversity of macroinvertebrates is higher in the upstream portion of the Bigaan River as compared to the downstream portion.

Macroinvertebrates are classified based on their tolerance to pollution. As shown in Table 4, majority of the macroinvertebrates are considered as pollution tolerant and two of these species, the aquatic worn and creeping water bug, were exclusively found in the downstream portion of the river. On the other hand, caddisfly and mayfly, which are both pollution sensitive species, were found only in the upstream portion of the river. The presence and abundance of mayfly and caddisfly indicates that the water quality in the upstream portion of the river is still in good status. Mayfly (Ephemeroptera) and caddisfly (Tricoptera) belong to the EPT taxa which are known to be pollution-sensitive and are composed of aquatic macroinvertebrates commonly used to assess the health status of stream and river. The presence or absence of the EPT taxa indicates if the aquatic environment is polluted or not.

Table 3: Diversity indices of macroinvertebrates in the 2 sampling stations of Bigaan River, Brgy. Gango, Libona, Bukidnon

\begin{tabular}{ccc}
\hline Diversity Indices & Downstream & Upstream \\
\hline Taxa_S & 7 & 7 \\
Individuals & 190 & 512 \\
Dominance_D & 0.4907 & 0.3045 \\
Simpson_1-D & 0.5093 & 0.6955 \\
Shannon_H & 1.091 & 1.431 \\
Evenness_e^H/S & 0.4252 & 0.5974 \\
\hline
\end{tabular}

Accordingly, these macroinvertebrates can only be found in streams and river with good water quality due to their low tolerance to pollution (Agouridis et al., 2015) and thus a strong bioindicator of a healthy aquatic environment. Conversely, the absence of mayfly and caddisfly in the downstream portion of the river implies that the quality of the water in the downstream portion is currently deteriorating and could not anymore support the survival of these pollutant-sensitive 
macroinvertebrates. In the study conducted by Souto et al. (2011), pollution sensitive groups including Ephemeroptera and Tricoptera were associated to the stream in the preserved area and the more tolerant groups were associated in the streams of the urban area.

Table 4: Pollution tolerance of macroinvertebrates found in the 2 sampling stations of Bigaan River, Brgy. Gango, Libona, Bukidnon

\begin{tabular}{cccc}
\hline Macroinvertebrates & Pollution Tolerance & $\begin{array}{c}\text { Down- } \\
\text { stream }\end{array}$ & $\begin{array}{c}\text { Up- } \\
\text { stream }\end{array}$ \\
$\begin{array}{c}\text { Aquatic worm } \\
\text { Creeping water bug }\end{array}$ & Pollution Tolerant & $\sqrt{ }$ & \\
Polden apple snail & Pollution Tolerant & $\sqrt{ }$ & \\
Leech & Pollution Tolerant & $\sqrt{ }$ & $\sqrt{ }$ \\
Water strider & Pollution Tolerant & $\sqrt{ }$ & $\sqrt{ }$ \\
Pyralid caterpillar & Moderately Tolerant & $\sqrt{ }$ & $\sqrt{ }$ \\
Whirligig beetle & Moderately Tolerant & & $\sqrt{ }$ \\
Water penny beetle & Pollution Sensitive & $\sqrt{ }$ & $\sqrt{ }$ \\
Caddisfly larvae & Pollution Sensitive & & $\sqrt{ }$ \\
Mayfly nymph & Pollution Sensitive & & $\sqrt{ }$ \\
\hline
\end{tabular}

As mentioned, the abundance of leech is higher in the downstream portion of the study area. Accordingly, majority of the common leech species as known to be inhabitants of eutrophic, polysaprobic and highly stressed freshwater environments (Lenat, 1993). Not all species of leech have high tolerance against various pollutants but the high level of tolerance of most common leech made all of them classified under the vast category of "highly tolerant organisms" used in biological assessment of freshwaters (Skriver et al., 2000). On the contrary, the high abundance of water strider, also a pollution tolerant species, in the upstream portion does not justify that the area is also polluted. Other factors might have contributed to the high abundance of water strider in the upstream portion and one might include the food source. As a predator, water strider prefers an environment abundant with insects which serves as its main source of food. Between the two sampling stations, the upstream portion of the river offers this type of environment with high abundance of insects as compared to the downstream portion (Table 2); hence, the high abundance of water strider was also observed.

Bioindicators are known to be strongly associated with some characteristics in its environment and any changes that occur in the habitat can be reflected on the distribution of bioindicators. Several studies have been conducted that utilizes macroinvertebrates as bioindicator in the assessment of aquatic ecosystems (Kaye, 2005; Duran, 2006; Haileselasie and Teferi, 2012; Henderson et al., 2012; Tampus et al., 2012; Selvanayagam and Abril, 2015). In this study, variation in the distribution as well as in the abundance of macroinvertebrates between the upstream and downstream portion of Bigaan River might be greatly influenced by the existence of smallscale mining activities in the downstream portion of the river. The mining activities have brought changes in the physical and chemical aspects of the water and causes mercury contamination in the river. Studies on other heavy metals such as in the assessment of lead mine pollution conducted by Mitchell (2009) using macroinvertebrates revealed that increased level of lead in the sampling sites have attributed to the reduction of species diversity.

Furthermore, characterization of the response of benthic macroinvertebrates to heavy metals released from the mines showed that although the concentration of heavy metals is not seriously high, their effects were reflected in the changes in species composition of macroinvertebrates particularly affecting the pollution sensitive EPT taxa and the decreased in total abundance and species richness as the concentration of heavy metals increases $(\mathrm{Qu}$ et al., 2010). Likewise, in this present study, although the concentration of mercury detected in the downstream portion of Bigaan River is low and still within the acceptable limit set by DAO-34, this concentration might still be detrimental to the aquatic macroinvertebrates especially for those species that are highly sensitive to pollutants like the EPT taxa. The species composition and total abundance of macroinvertebrates have varied between the two sampling sites wherein the member of Ephemeroptera and Tricoptera taxa were only found in the downstream portion and the abundance of macroinvertebrates in the downstream portion is significantly lower than the upstream portion of Bigaan River.

Aside from mercury contamination, other water quality parameters such as increased total suspended solid and total hardness might have also contributed to the lesser species diversity in the downstream portion of the river. As cited by Chakravorty et al. (2014), high suspended solid not only reduces the rate of photosynthesis but also damages the exposed organs of macroinvertebrates and causes macroinvertebrate dislodgements (Langer, 1980) and is associated with an increased in macroinvertebrate migration (Gamon, 1970). Water hardness, on the other hand, has the capacity to modify the toxicity of heavy metals to aquatic organisms (Khan and Ghosh, 2001). Accordingly, the bioavailability of heavy metals including mercury in freshwater typically decreases as the water hardness increases (USEPA, 1995). Although this claim was not fully established in this study, the increased water hardness in the downstream portion of Bigaan River might possibly explain the low mercury level that is still within the standards set by DAO-34 even though gold mining activities occur in the area.

\section{Conclusion}

The physicochemical parameters and the diversity and distribution of macroinvertebrates varied between the upstream and downstream portion of Bigaan River in Brgy. Gango, Libona, Bukidnon. The existing small scale mining activities in the area, which caused increase turbidity and mercury contamination in the river, is main identified factor for the observed variation. Assessment of macroinvertebrates as bioindicator 
reveals that the water quality of the downstream portion of Bigaan River is deteriorating as evidenced by the absence of pollution sensitive Ephemeroptera and Tricoptera taxa. Although the level of mercury contamination is low and within the standard limit, the consequence is still evident indicating that long term exposure to mercury has detrimental effects on the macroinvertebrate communities along the small scale mining area in Brgy. Gango, Libona, Bukidnon.

\section{References}

Agouridis CT, Wesley ET, Sanderson TM, and Newton BL (2015). Aquatic macroinvertebrates: Biological indicators of stream health. Agriculture and Natural Resources Publications, University of Kentucky, Lexington, USA: 1-6. Available online at: http://uknowledge.uky.edu/anr_reports/175

Benetti CJ, Pérez-Bilbao A, and Garrido J (2012). Macroinvertebrates as indicators of water quality in running waters: 10 years of research in rivers with different degrees of anthropogenic impacts. In: Voudouris K and Voutsa D (Eds.) Ecological water quality-water treatment and reuse: 95-122. InTech Open Access Publisher, Rijeka, Croatia.

Bonada N, Prat N, Resh VH, and Statzner B (2006). Developments in aquatic insect biomonitoring: A comparative analysis of recent approaches. Annual Review of Entomology, 51: 495523.

Chakravorty PP, Sinha M, and Chakraborty SK (2014). Impact of industrial effluent on water quality and benthic macro invertebrate diversity in fresh water ponds in Midnapore district of west Bengal, India. Journal of Entomology and Zoology Studies, 2(3): 93-101.

Davis AJ, Holloway JD, Huijbregts H, Krikken J, Kirk-Spriggs AH, and Sutton SL (2001). Dung beetles as indicators of change in the forests of northern Borneo. Journal of Applied Ecology, 38(3): 593-616.

Duran M (2006). Monitoring water quality using benthic macroinvertebrates and physico-chemical parameters of Behzat stream in Turkey. Polish Journal of Environmental Studies, 15(5): 709-717.

Gamon JR (1970). The effect of inorganic sediment on stream biota. Water pollution Control Research Series 18050 DWC12/70, Environmental Protection Agency, Water Quality Office, Washington, USA.

Haileselasie TH and Teferi M (2012). Influence of water quality on the diversity and distribution of Macro-Invertebrates in Hiwane second order stream, Northern Ethiopia. Research Journal of Environmental and Earth Sciences, 4(4): 475-481.

Henderson BL, Chumchal MM, Drenner RW, Deng Y, Diaz P, and Nowlin WH (2012). Effects of fish on mercury contamination of macroinvertebrate communities of grassland ponds. Environmental Toxicology and Chemistry, 31(4): 870-876.

Hickin EJ (1995). Hydraulic geometry and channel scour, Fraser River, British Columbia, Canada. In: Hickin EJ (Ed.), River Geomorphology: 155-167. Wiley, Chichester, UK.

Kaye A (2005). The effects of mine drainage water from Carrock Mine on the water quality and benthic macroinvertebrate communities of Grainsgill Beck: A preliminary study. Earth \& Environment, 1: 120-154.

Khan RA and Ghosh LK (2001). Faunal diversity of aquatic insects in freshwater wetlands of South Eastern West Bengal. Zoological Survey of India (ZSI), Kolkata, India, 194: 28-59.

Kitching RL, Orr AG, Thalib L, Mitchell H, Hopkins MS, and Graham AW (2000). Moth assemblages as indicators of environmental quality in remnants of upland Australian rain forest. Journal of applied Ecology, 37(2): 284-297.

Kripa PK, Prasanth KM, Sreejesh KK, and Thomas TP (2013). Aquatic macroinvertebrates as bioindicators of stream water quality: A case study in Koratty, Kerala, India. Research Journal of Recent Sciences, 2: 217-222.

Langer OE (1980). Effects of sedimentation on salmonoid stream life. In: Weagle K (Ed.), Report on the Technical Workshop on suspended solids and the aquatic environment: 1-21. Department of Indian Affairs and Northern Development, Whitehorse, Yukon Territory, Canada.

Lenat DR (1993). A biotic index for the Southeastern United States: Derivation and list of tolerance values, with criteria for assigning water-quality ratings. Journal of the North American Benthological Society, 12(3): 279-290.

McGEOGH MA (1998). The selection, testing and application of terrestrial insects as bioindicators. Biological Reviews, 73(2): 181-201.

Mitchell JW (2009). An assessment of lead mine pollution using macro-invertebrates at Greenside Mines, Glenridding. Earth \& Environment, 4: 27-57.

Qu X, Wu N, Tang T, Cai Q, and Park YS (2010). Effects of heavy metals on benthic macroinvertebrate communities in high mountain streams. Annales de Limnologie-International Journal of Limnology, 46(4): 291-302.

Selvanayagam M and Abril R (2015). Water quality assessment of Piatua river using macroinvertebrates in Puyo, Pastaza, Ecuador. American Journal of Life Sciences, 3(3): 167-174.

Sharma MP, Sharma S, Goel V, Sharma P, and Kumar A (2008). Water quality assessment of Ninglad stream using benthic macroinvertebrates. Life Science Journal, 5(3): 67-72.

Skriver J, Friberg N, and Kirkegaard J (2000). Biological assessment of running water in Denmark: Introduction of the Danish stream fauna index (DSFI). International Association of Theoretical and Applied Limnology, 27: 1822-1830.

Souto RMG, Facure KG, Pavanin LA, and Jacobucci GB (2011). Influence of environmental factors on benthic macroinvertebrate communities of urban streams in Vereda habitats, Central Brazil. Acta Limnologica Brasiliensia, 23(3): 293-306.

Tampus AD, Tobias EG, Amparado RF, Bajo L, and Sinco AL (2012). Water quality assessment using macroinvertebrates and physico-chemical parameters in the riverine system of Iligan City, Philippines. Advances in Environmental Sciences, $4(2): 59-68$.

UNEP (2008). Module 3: Mercury use in artisanal and small scale gold mining. United Nations Environment Programme, Nairobi, Kenya. Available online at: http://www.unep.org

UNEP (2013a). Mercury - Time to act. United Nations Environment Programme. Nairobi, Kenya. Available online at: http://www.unep.org

UNEP (2013b). Global mercury assessment- sources, emissions, releases and environmental transport. United Nations Environment Programme, Nairobi, Kenya. Available online at: http://www.unep.org

USEPA (1995). Stay of federal water quality criteria for metals; Water quality standards; Establishment of numeric criteria for priority toxic pollutants; States compliance revision of metal criteria; Final rules. United Sates Environmental Protection Agency (Federal Register), Washington, USA, 60(86): 22237222228.

WHO (2007). Exposure to mercury: A major public health concern. World Health Organization, Geneva, Switzerland. Available online at: http://www.who.int/ipcs/features/ mercury.pdf 